\title{
Defects of Tensioned Membrane Structures (TMS) in the Tropics
}

\section{ABSTRACT}

The wide use of tensioned membrane structures (TMS) becomes prominent in many designs because of its aesthetic, ergonomic, and economical nature. Recently, TMS has been applied in the tropics with success, yet defects specific to this region have received little attention. Through a questionnaire survey of 890 uses and technicians of TMS in three different areas in Malaysia, this study identified the most frequently occurring TMS defects in the tropics, such as "deterioration of roof coatings", "corrosion or fatigue in fixings", "fungal decay, mould growth, and dirt in membrane", "corrosion in anchor cables", and "degradation of fabrics". These defects are quite different from those in other climatic zones. The top five causes of TMS defects in the tropics are weather, aging, design, construction/installation, and material selection. However, only "corrosion or fatigue in fixings" is a significant predictor for "deterioration of roof coatings". While this is not a causal effect, a practical implication is that TMS maintenance workers do not have to climb up to the roof to check the deterioration in coating but only need to predict the deterioration through the corrosion levels of the fixings. Further, seven countermeasures for TMS in tropic are recommended. This study is the first comprehensive study examining tensioned membrane structure defects in the tropics.

Keywords: tensioned membrane structure, defects in TMS, membrane structure, tensioned structure, deterioration of roof coatings 


\section{Introduction}

Nowadays, the wide use of tensioned membrane structures (TMS) has featured prominently in many architectural designs because of its aesthetic and ergonomic nature (Tan, 2011; Gosling et al., 2013a). Tensioned membrane structures are part of a developing technology which gives designers, architects and engineers the ability to experiment with form and creates exciting new solutions to conventional design problems (Toyoda \& Takahashi, 2013; Shaeffer, 1996). TMS is not only visually exciting but also environmentally sensitive and economically competitive (Guo, 2008; Habib \& Rokonuzzaman, 2011). While the first TMS was built by the Russian engineer Vladimir Shukhov in the Nizhny Novgorod Fair in 1896, the modern era of TMS is considered to have begun with a small bandstand designed and built by Frei Otto for the Federal Garden Exhibition in Cassel, Germany in 1955. Otto was a key pioneer in the development of tensile structures and he inspired many others to use TMS (Shaeffer, 1996). The approach integrates structural mechanicals, architecture, chemistry, and material science. Recently, TMS has been used in the tropics to construct a variety of structures including stadiums, exhibition halls, shopping complexes, convention centers, amphitheatres, community halls, and transport terminals (Toyoda \& Takahashi, 2013; Gosling et al., 2013b). In Malaysia, the largest membrane structure built was the Bukit Jalil Sports Complex, completed in 1998 for the Commonwealth Games. However, Supartono (2011) argued that defect can occur in TMS due to the flexible nature coupled with improper installation or by mistakes in the membrane cutting or pattern design. A cracked membrane surface may induce higher stress in other parts of the membrane surface (Huntington, 2009). Defects may also occur due to weather conditions (e.g., strong winds or rain during the installation of 
pre-tensioning). As weather patterns in the tropics are different to other regions, these unique conditions of moisture, temperature, and solar radiation mean that the types and causes of TMS defects in the tropics may differ from other climatic zones (Gosling et al., 2013b; Tian, 2011; Supartono, 2011). The aim of this research is to identify the types and causes of defects in TMS erected in the tropics and to identify key measures to improve future use and maintenance of TMS in tropical regions.

\section{Tensioned Membrane Structures (TMS) and Applications}

TMS is a spatial shape formed by interior pretension from multiple strong and thin membrane materials (e.g., polyvinyl chloride (PVC)) and reinforcement members (e.g., a steel structure, steel posts, or steel cable) (Foster, 2000; Toyoda \& Takahashi, 2013). The tensioned membrane structure is put into tension using either of two methods. Materials can be stretched materials over compression supports and anchored either to the ground or to the heads of shorter braced columns (in the manner of the traditional circus tent on its poles); alternatively, the membrane structure can be suspended using tension supports (usually cable hangers) and then anchored to the ground (Foster et al., 2007). TMS currently represents the mainstream of membrane design and construction. Due to the pleasing aesthetics, designers favor the use of a curved shape for TMS. The tension is induced in the membrane in addition to any self-weight and live loads they may carry, with the objective of ensuring that the usually flexible structural elements remain stiff under all working loads (Supartono et al, 2011). The level of pretension determines the shape of membrane structure and tension can be applied to the membrane structure by stretching from its edges or by pre-tensioning the cables which support the membrane and therefore change its shape (Supartono et al., 2011). The internal force path of TMS is more complex than found in frame structures 
so that the structural design, cutting pattern design, and the installation of TMS must be completed with high precision.

There are two other types of membrane structures in addition to TMS, namely: pneumatic structures (e.g., air stabilized; also known as air-supported or air-inflated membrane structures) and frame membrane structures (Brew \& Lewis, 2013). Pneumatic structures rely on air pressure being continuously created within the membrane structure to inflate the membrane until it becomes stiff enough to support its own weight and any surface loads. Frequently, a pressure of approximately 3/1000 higher than the atmospheric pressure must be applied and should remain constant during operation (Supartono et al., 2011). The frame membrane structure is composed by a self-stable frame that is covered with a membrane. The frame structure can be steel frame, steel space frame, or space truss. The membrane should be calculated as a plane stress element so that the external loads are carried by tensile stresses induced in the membrane surface only, referred to as 'membrane stresses' (Supartono et al., 2011).

\section{Materials used in TMS}

TMS is also known as a 'fabric structure' because it is made of fabric and tensioned membrane elements. The fabric or membrane elements make TMS unique and distinct from other structures (Supartono, et al., 2011). Membrane materials commonly consist of PVC, PTFE (polytetrafluoroethylene), HDFE (high-density polyethylene), and ETFE (ethylene tetrafluoroethylene) (Nunes, 2012).

\section{PVC (Polyvinyl chloride)}


PVC is a translucent fabric which has been widely used for over 20 years for membrane structures. The fabric is composed of high strength fibers such as polyamide, polyester, or polyvinyl; resistance to ultraviolet (UV) rays can enhanced by the addition of white pigments (Gosling et al., 2013a).

\section{PTFE (polytetrafluoroethylene)}

This material is based on a glass fiber cloth and surface lining of polytetrafluoroethylene (PTFE); no surface treatment is required when used as a membrane material as PTFE is chemically very stable (Supartono et al., 2011). Generally, PTFE has better strength, durability, and self-cleaning performance than PVC membranes, but is more expensive. PTFE has high fire resistance; a lifespan exceeding 25 years; it is unaffected by UV rays; is chemically inert but bleaches white when exposed to sunlight; limited colors are generally available, although specific hues can be custom-made; and it has around 25\% translucency, which provides a diffused light in the interior and reduces the need for supplementary lighting.

\section{ETFE (Ethylene tetrafluoroethylene)}

ETFE is created from a thin layer of ethylene tetrafluoroethylene. When used in a membrane, this material is much more transparent than PVC or PTFE membranes due to the thinness of the layer (with a transparency rate of $90 \%)$. This transparency means that it can, to an extent, replace glass as a transparent roofing material (Supartono et al., 2011); however, ETFE has less strength than other materials and usually requires a base fabric for additional support. ETFE is more applicable in the frame membrane structure or air supported membrane structure than TMS.

\section{HDFE (high-density polyethylene),}


HDFE fabric is a cost effective material designed for basic modular structures. HDFE is suited to large commercial projects where specifications require the fabric to be exposed to environmental conditions including wind, rain, dust, and UV exposure (Nunes, 2012).

In the tropics, the frame and cables of TMS are constructed of steel. Protection against corrosion is accomplished by adding a clear PVC coat to the cables and a smooth layer of powder coat over a base of primer for the frames. The materials carry loads are mainly through tensile stresses. The materials used for TMS in the tropics possess the following characteristics: a) high strength, b) good heat insulation, c) sound insulation, d) low flammable rates, and e) self-cleaning.

\section{Parts of TMS in Construction}

There are four key elements that must be considered in when designing or constructing TMS: membranes, anchorages, cables and ropes, and access openings.

\section{Membranes}

Membranes are normally made of highly tensioned fabrics but may also be constructed of coated fabrics, plastic films, woven metallic fabrics, or metallic foils (Gosling et al., 2013b). The fabrics consist of a terylene or nylon fabric coating on one or both sides with a plasticized elastomer (e.g., neoprene or vinyl), or of woven glass fibre coated with Teflon or silicone (Foster et al., 2007). There are single tent membranes, most suitable for areas which do not need heating habitable standards; alternatively, twoskin membranes with wool or mineral fibre insulation can provide greater thermal insulation (Seidel, 
2009). Moreover, there are tubes in air inflated tube structure which are commonly in the form of a circular woven fabric sleeve with an inner airtight elastomer lining and an outer weather resistant coating of similar materials (Pargana et al., 2008). The method of joining membranes together depends on the specific materials used; frequently, the joins between membranes are achieved using a sewn double-folded seam, cementing, or heat welding.

\section{Anchorages}

Anchors are used to secure a membrane or a cable to supporting masonry. Direct or positive anchorage into the ground is used for membrane structures that are to be in position for long periods of time (Loong et al., 2007). This allows the TMS to be secured over the perimeter to a continuous concrete foundation. The bottom edge of the membrane can be ended with a rope welt which may be clamped to a continuous timber cill piece either using coach screws or bolts passing through steel angles, or timber battens; the cill piece is rag bolted at intervals to the concrete strip foundation (Gosling et al., 2013b). Other methods of positive anchorage involves the use of pipes or cables, accommodate in fabric sleeves or hems attached to the membrane, which are secured to anchors at intervals round the perimeter. There are two types of anchors for tent structures. First, pipes are inserted in a hem round the base of the membrane, allowing these to be attached to ground anchors at cut-outs in the hem at $1 \mathrm{~m}$ intervals. Alternatively, the rope or cable can pass through shaped fabric sleeves sewn into the base of the membrane, allowing it to be secured at intervals to the ground anchors (Foster et al., 2007).

\section{Cables and Ropes}


TMS uses steel, nylon, or polyester cables to divide air supported membranes into smaller elements. Chafing or friction from small movements can cause wear on the membrane as the two components move relative to each other. This problem can be solved by placing cables internally and then attaching the membrane to them using dropped skirts and lacing (Foster et al., 2007). The ridge and valley cables cause the chafing in tent structures. This can be avoided by carefully placing the cable externally along the ridge line and linking the membrane to it using metal connectors (Loong et al., 2007; Beatini \& Royer-Carfagni, 2013)

\section{Access Openings}

TMS requires air locks or air curtains. There is a vane to provide a counterbalance and to make opening easy.

\section{Features, Advantages, and Applications of TMS}

Common features of TMS that make it popular include its: a) transparency, b) light-weight structure, c) fire resistance and durability, d) self-cleaning properties, and e) large spans with open spaces.

Transparency - The transparency of the materials contributes to the creation of a bright space illuminated by natural light. The sunlight allows the building to be full of natural and diffuse light in the daytime. At night, interior lamp light permeates the TMS membranes to increase illumination of nearby night scenery. When the membrane is used in gymnasium and entertainment facilities, a large space can 
This is a copy of the 'Post-print'; i.e., final draft post-refereeing.

Wang, C., Abdul-Rahman, H., Wood, L. C., Mohd-Rahim, F. A., Zainon, N., \& Saputri, E. (in press). Defects Of Tensioned Membrane Structures (TMS) in the

Tropics, Journal of Performance of Constructed Facilities

be achieved with continual lighting throughout the day and suitable commercial spaces established for comfort can be created.

Light-weight structure- TMS has the potential to contribute to disaster prevention and relief efforts as TMS materials are generally lighter than other constructional materials. Membrane materials in the roofing contribute to the strong aseismatic performance and safety characteristics of TMS (Gosling et al., 2013a). During disasters, temporary refuge, emergency rescue center gymnasiums, and disaster relief command centers can be created using multifunctional TMS facilities, providing lots of useable spaces.

Fire resistance and durability- TMS buildings with PTFE or PVC membranes are characterized by high levels of heat and fire resistance, weather resistance, drug resistance, and high strength. The materials age well and can be maintained to keep their initial strength even after long periods of use.

Self-cleaning properties- The surface painting of the PTFE membrane material is polytetrafluoroethylene resin, the same surface coating used on most non-stick cookware. The surface of the PTFE tensioned membrane materials resists dirt and dust coatings; any build-up that occurs can be easily cleaned away by rainwater. This creates a low-maintenance and easily cleaned surface.

Large spans with open spaces - The membrane material for the membrane structural building is very light, at about $1 \mathrm{~kg}$ per square meter. TMS can create huge, non-column spaces, providing open areas of significant size. 
Tian (2011) listed the following advantages of TMS: a) aesthetic and translucent, b) cost effective to provide roofing to either new or existing areas, c) low maintenance compared to glass, d) able to disperse natural light with condensed heat load (excellent alternative to polycarbonate or glass as roof glazing system), e) absorbs solar energy (4\%-17\%) and reduces the heat load, f) higher transmission of light during daytime (sufficient to reduce artificial lighting requirements by 5-20\%), g) larger span for more coverage, h) no extension joints as the membranes structures are welded into a single weatherproof skin, i) minimal site interruptions since the membranes structures are manufactured in factories before being transported to site for assembly, and j) suitable for rapid construction on site.

Applications of TMS in building facilities (Nunes, 2012; Supartono et al., 2011; Shaeffer, 1996) include: a) sport facilities; e.g., stadiums, gymnasiums, fitting centers, basketball courts, swimming pools, and tennis courts; b) transportation facilities; e.g., bus stations, airports, railway stations, toll stations, ports, gas filling stations, and elevated corridors; c) commercial facilities; e.g., malls, hotels, restaurants, shopping centers, and commercial street-side facilities; d) industrial facilities; e.g., in a factories, warehouses, green houses, sewage treatment centers, scientific research centers, and logistics centers; e) landscape facilities; e.g., landscape works, park works, building entrances, music plazas, beach entertainment and leisure buildings, community spaces, parking lots, and amusement plazas; f) interior building; e.g., decorations, halls, interior models, and entrances; and g) flagship building; e.g., exhibition halls, entrance landmarks, urban and regional landmark.

\section{Defects in TMS}


A building is considered as defective when there are shortcomings or failings in the function, performance, or statutory or user requirements of a building. These may be apparent within the structure, fabric, services, or other facilities of the affected building (Khoo, 2011; Campbell, 2001; Low \& Wee, 2001; Li \& Yuan, 2013). Defects in TMS can be split into three categories (Sommerville \& McCosh, 2007): a) aesthetic, when a building element or material is unfavorably affected or fails to be visually pleasing; b) functional, when a building fails to perform its intended function or manner; and c) technical, when the workmanship, design, or materials of an element decrease its capacity to functionally perform. Table 1 lists some common types of defects in TMS together with the relevant authors.

Table 1: Types of defects in TMS

\begin{tabular}{|c|c|}
\hline Type of Defects & Authors \\
\hline $\begin{array}{l}\text { Membranes/fabrics } \\
\text { Fabric tearing } \\
\text { i. The fabric may be folding or scratched } \\
\text { i. Wrinkling of fabric } \\
\text { Flapping and fluttering of the fabric } \\
\text { Degradation of fabric } \\
\text { Fungal decay, mould growth, and dirt in membrane }\end{array}$ & $\begin{array}{l}\text { Shaeffer (1996); Foster (2007); Foster } \\
\text { (2000); Cheng (2007); Supartono et al. } \\
\text { (2011); Gosling et al. (2013a) }\end{array}$ \\
\hline $\begin{array}{l}\text { Anchorage } \\
\text { i. } \quad \text { Corrosion in anchor cables } \\
\text { i. } \quad \text { Deflection of anchors }\end{array}$ & $\begin{array}{l}\text { Cheng (2007); Foster (2007); Foster } \\
\text { (2000) }\end{array}$ \\
\hline $\begin{array}{l}\text { Cables/ropes } \\
\text { Slack or drooping cable/ropes } \\
\text { i. } \quad \text { Corrosion in cables }\end{array}$ & $\begin{array}{l}\text { Shaeffer (1996); Foster (2007); Cheng } \\
\text { (2007); Tian (2011); Gosling et al. } \\
\text { (2013b) }\end{array}$ \\
\hline Mast/pole & Foster (2000); Cheng (2007) \\
\hline
\end{tabular}


This is a copy of the 'Post-print'; i.e., final draft post-refereeing.

Wang, C., Abdul-Rahman, H., Wood, L. C., Mohd-Rahim, F. A., Zainon, N., \& Saputri, E. (in press). Defects Of Tensioned Membrane Structures (TMS) in the

Tropics, Journal of Performance of Constructed Facilities

\begin{tabular}{|c|c|}
\hline $\begin{array}{ll}\text { i. } & \text { Deflection of the mast } \\
\text { i. } & \text { Change of mast position }\end{array}$ & \\
\hline $\begin{array}{l}\text { Rings and arches } \\
\text { i. } \quad \text { Corrosion of the rings and arches }\end{array}$ & $\begin{array}{l}\text { Macdonald (2001); Shaeffer (1996); } \\
\text { Foster (2007); Cheng (2007); Gosling et } \\
\text { al. (2013a) }\end{array}$ \\
\hline $\begin{array}{l}\text { Fixings } \\
\text { i. } \quad \text { Corrosion or fatigue in fixings }\end{array}$ & $\begin{array}{l}\text { Tian (2011); Foster (2000); Li \& Yuan } \\
\text { (2013) }\end{array}$ \\
\hline $\begin{array}{l}\text { Foundation } \\
\text { i. } \quad \text { Cracks in foundations }\end{array}$ & Shaeffer (1996); Macdonald (2001) \\
\hline $\begin{array}{l}\text { Roof } \\
\text { i. } \quad \text { Deterioration of roof coatings }\end{array}$ & $\begin{array}{l}\text { Cheng (2007); Shaeffer (1996); } \\
\text { Macdonald (2001); Foster et al. (2007) }\end{array}$ \\
\hline $\begin{array}{l}\text { Services } \\
\text { i. } \quad \text { Lighting breakdown } \\
\text { i. } \quad \text { Lack of water drainage and pooling of water }\end{array}$ & $\begin{array}{l}\text { Foster et al. (2007); Foster (2000); } \\
\text { Supartono et al. (2011) }\end{array}$ \\
\hline
\end{tabular}

Sommerville (2007) states that design problems contributed to 50\% of the defects found in construction projects, $40 \%$ of defects occurred during the construction process and $10 \%$ could be attributed to the failure of materials. Many authors have discussed the various causes of defective works in construction industry and Table 2 shows the categories of causes of building defects.

Table 2: Causes of defects in buildings

\begin{tabular}{|l|l|}
\hline \multicolumn{1}{|c|}{ Causes of Defects } & \multicolumn{1}{|c|}{ Authors } \\
\hline Weather & Shaeffer (1996); Richardson (2001); Low \& Wee (2001); Cheng (2007) \\
\hline Design & Richardson (2001); Low \& Wee (2001); Cheng (2007) \\
\hline Construction/ installation process & Foster et al. (2007); Richardson (2001); Cheng (2007) \\
\hline Aging & Richardson (2001); Cook \& Hinks (1992) \\
\hline User involvement & Richardson (2001); Cheng (2007) \\
\hline Cost pressure & Foster et al. (2007); Low \& Wee (2001) \\
\hline
\end{tabular}




\begin{tabular}{|l|l|}
\hline Workmanship & Richardson (2001); Low \& Wee (2001) \\
\hline Material selection & Shaeffer (1996); Foster et al. (2007); Richardson (2001); Cheng (2007), \\
\hline Fabrication techniques & Cheng (2007); Ilozor et al. (2004) \\
\hline Lack of quality & Shaeffer (1996); Cheng (2007) \\
\hline
\end{tabular}

\section{Research Design and Methods}

A questionnaire or survey is a good method to overcome the challenge of working with a large population and to gain data from various individuals (Khoo, 2011); thus, a questionnaire was employed in this study. We selected three areas in Klang Valley (Malaysia) where TMS is a commonly used building style: Amphitheatre in University of Malaya, Alamanda in Putrajaya, and Central Market in Kuala Lumpur. 890 questionnaires were distributed to TMS users andt his resulted in 96 respondents who provided complete and valid feedback (a response rate of $10.79 \%$ ). Table 3 shows the numbers and percentages of respondents in these three areas in Klang Valley. The respondents' demographic profiles are further illustrated in Table 4.

Table 3: Distribution of respondents by areas

\begin{tabular}{|l|c|c|}
\hline \multicolumn{1}{|c|}{ TMS } & Number of the respondents & Percentage (\%) \\
\hline Amphitheatre in University of Malaya & 45 & 46.88 \\
\hline Alamanda in Putrajaya & 24 & 25.00 \\
\hline Central Market in Kuala Lumpur & 27 & 28.12 \\
\hline Total & 96 & 100.00 \\
\hline
\end{tabular}


There are three main ethnic groups in Malaysia: Malay, Chinese, and Indian. Among the 96 respondents, 61.5\% were Malays, $22.9 \%$ were Chinese, $11.5 \%$ were Indians, and $4.2 \%$ were foreigners staying in Malaysia (e.g., Indonesian, Iranian, and Sudanese); this roughly representative with the ethnic mix of the wider population in Malaysia. The number of male (52.1\%) and female (47.9\%) respondents were roughly equal. Most respondents were below 31 years old with 78.1\% of respondents between 18 to 25 years old. Only 4.1\% respondents were older than 40. Most respondents were educated at the Tertiary level (94.8\%). Among these 96 respondents, 19.8\% were TMS technicians who installed and maintained the TMSs and $66.7 \%$ were daily users of TMSs. The other $13.5 \%$ were occasional users of these TMSs.

Table 4: Respondents' Profiles

\begin{tabular}{|c|c|c|c|}
\hline Social-demographic characteristics & $\begin{array}{c}\text { Frequency } \\
(\mathrm{n}=96)\end{array}$ & Valid Percentage & $\begin{array}{l}\text { Cumulative } \\
\text { Percentage }\end{array}$ \\
\hline \multicolumn{4}{|l|}{ Gender } \\
\hline - $\quad$ Male & 50 & 52.1 & 52.1 \\
\hline - $\quad$ Female & 46 & 47.9 & 100.0 \\
\hline \multicolumn{4}{|l|}{ Race } \\
\hline - $\quad$ Malays & 59 & 61.5 & 61.5 \\
\hline - $\quad$ Chinese & 22 & 22.9 & 84.4 \\
\hline - $\quad$ Indians & 11 & 11.5 & 95.8 \\
\hline - $\quad$ Others & 4 & 4.2 & 100.0 \\
\hline \multicolumn{4}{|l|}{ Age } \\
\hline $18-25$ year old & 75 & 78.1 & 78.1 \\
\hline - $\quad 26-30$ year old & 10 & 10.4 & 88.5 \\
\hline 31-40 year old & 7 & 7.3 & 95.8 \\
\hline 41-50 year old & 3 & 3.1 & 99.0 \\
\hline - $\quad$ More than 50 year old & 1 & 1.0 & 100.0 \\
\hline Education level & & & \\
\hline
\end{tabular}




\begin{tabular}{|l|c|c|c|}
\hline$\bullet \quad$ Primary & 1 & 1.0 & 1.0 \\
$\bullet \quad$ Secondary & 4 & 4.2 & 5.2 \\
\hline$\quad$ Tertiary & 91 & 94.8 & 100.0 \\
\hline$\quad$ Type of User regarding TMS & 19 & 19.8 & 19.8 \\
$\quad$ Daily Users & 64 & 66.7 & 86.5 \\
\hline$\quad$ Occasional Users & 13 & 13.5 & 100.0 \\
\hline
\end{tabular}

The questionnaire form was designed with three sections. Section A captures the profiles of respondents and Section B identifies common types of TMS defects found in the tropics and how frequently these occur. A four-level rating scale was used for the frequency of each type of defect (viz., never, rare, frequent, and very frequent). Section $\mathrm{C}$ captured data on the causes of defects, where the respondents had to identify causes of defects; e.g., weather, design, installation process, aging, user involvement, time pressure, cost pressure, workmanship, material selection, and fabrication techniques. Respondents were allowed to select multiple causes in this section.

The data were analyzed using Cronbach’s alpha, frequency analysis, scale index analysis, Pearson’s correlation, regression tests, and one way ANOVA. Since a relative high value of Cronbach's alpha is commonly used as evidence that particular items measure an underlying construct, Cronbach’s alpha test was used to identify the internal consistency of items in this survey to gauge the reliability. Pearson's correlation coefficient was used to measure the strength of relationship between pairs of variables. It is often signified by r (rho) and the value ranged from -1.0 to 1.0. A coefficient of -1.0 indicates perfect negative correlation, 0.0 indicates no correlation, and 1.0 shows perfect positive correlation (Pavkov and Pierce, 2007). The multiple regressions were specifically used in this research to find appropriate 
indicators of a defect that can be used in maintenance operations. One way ANOVA allowed us to compare the means of unrelated samples.

\section{Data Analysis and Interpretations}

\section{Reliability Test Result for Variables}

The statistical result of Cronbach's values identified the consistency of the 18 variables in the questionnaire form. The Cronbach's alpha coefficient at 0.840 revealed a reasonable level of internal consistency; values in excess of 0.8 are considered acceptable (Bryman \& Cramer, 2001). Table 5 lists the reliability for the measures of all 18 types of defects that occur in TMS in the tropics.

Table 5: Item-total Statistics

\begin{tabular}{|c|c|c|c|c|c|}
\hline No & Type of Defects & $\begin{array}{l}\text { Scale Mean if } \\
\text { Item Deleted }\end{array}$ & $\begin{array}{l}\text { Scale Variance } \\
\text { if Item Deleted }\end{array}$ & $\begin{array}{l}\text { Corrected Item- } \\
\text { Total Correlation }\end{array}$ & $\begin{array}{c}\text { Cronbach's } \\
\text { Alpha if Item } \\
\text { Deleted }\end{array}$ \\
\hline 1 & Fabrics tearing & 42.18 & 38.463 & .342 & .837 \\
\hline 2 & The fabric may folding or scratched & 42.18 & 38.105 & .411 & .833 \\
\hline 3 & Wrinkling of the fabric & 42.17 & 37.172 & .503 & .829 \\
\hline 4 & Flapping and fluttering of the fabric & 42.23 & 36.936 & .485 & .830 \\
\hline 5 & Degradation of fabric & 42.08 & 37.677 & .500 & .829 \\
\hline 6 & Fungal decay, mould growth, and dirt in membrane & 42.00 & 38.063 & .403 & .834 \\
\hline 7 & Corrosion in anchor cables & 42.02 & 37.136 & .491 & .829 \\
\hline 8 & Deflection of anchors & 42.24 & 36.184 & .563 & .825 \\
\hline
\end{tabular}


This is a copy of the 'Post-print'; i.e., final draft post-refereeing.

Wang, C., Abdul-Rahman, H., Wood, L. C., Mohd-Rahim, F. A., Zainon, N., \& Saputri, E. (in press). Defects Of Tensioned Membrane Structures (TMS) in the

Tropics, Journal of Performance of Constructed Facilities

\begin{tabular}{|l|l|l|l|l|l|}
\hline 9 & Slack or drooping cable/ropes & 42.24 & 38.226 & .400 & .834 \\
\hline 10 & Corrosion in cables & 42.13 & 37.774 & .454 & .831 \\
\hline 11 & Deflection of the mast & 42.28 & 36.857 & .514 & .828 \\
\hline 12 & Change of mast position & 42.35 & 37.873 & .393 & .834 \\
\hline 13 & Corrosion of the rings and arches & 42.11 & 36.334 & .612 & .823 \\
\hline 14 & Corrosion or fatigue in fixings & 41.99 & 38.179 & .390 & .834 \\
\hline 15 & Cracks in foundations & 42.26 & 36.658 & .466 & .831 \\
\hline 16 & Deterioration of roof coatings & 41.93 & 36.974 & .469 & .830 \\
\hline 17 & Lighting breakdown & 42.41 & 39.507 & .210 & .843 \\
\hline 18 & Lack of water drainage and pooling of water & 42.19 & 39.480 & .219 & .842 \\
\hline
\end{tabular}

\section{Frequency of TMS Defects in the Tropics}

We determined the five most frequently occurring defects in tropical TMS. Table 6 illustrates the frequency rankings of these defect types. The highest mean value is 2.72 ("deterioration of roof coatings”), indicating the most frequently occurring TMS defect in the tropics, closely followed by “corrosion or fatigue in fixings" with the second highest mean value (2.66). "Fungal decay, mould growth, and dirt in membrane” was ranked third (mean value of 2.65). The fourth and fifth most common defects are “corrosion in anchor cables” and “degradation of fabrics”, respectively.

Table 6: Frequency Ranking of Defects in TMS in Tropic

\begin{tabular}{|c|c|c|c|c|c|c|c|c|c|c|c|}
\hline \multirow{2}{*}{ Type of Defects } & \multicolumn{2}{|c|}{ Never } & \multicolumn{2}{|c|}{ Rarely } & \multicolumn{2}{|c|}{ Frequent } & \multicolumn{2}{|c|}{ Very Frequent } & \multirow{2}{*}{ Mean } & \multirow{2}{*}{$\begin{array}{l}\text { Standard } \\
\text { Deviation }\end{array}$} & \multirow{2}{*}{ Rank } \\
\hline & Frequency & $(\%)$ & Frequency & $(\%)$ & Frequency & $(\%)$ & Frequency & $(\%)$ & & & \\
\hline \multicolumn{12}{|l|}{ Membranes/fabric } \\
\hline Fabrics tearing & 5 & 5.2 & 46 & 47.9 & 40 & 41.7 & 5 & 5.2 & 2.47 & 0.68 & 10 \\
\hline $\begin{array}{l}\text { The fabric may folding, } \\
\text { scratches }\end{array}$ & 3 & 3.1 & 50 & 52.1 & 38 & 39.6 & 5 & 5.2 & 2.47 & 0.65 & 9 \\
\hline Wrinkling of the fabrics & 5 & 5.2 & 45 & 46.9 & 41 & 42.7 & 5 & 5.2 & 2.48 & 0.68 & 8 \\
\hline $\begin{array}{l}\text { Flapping and fluttering of } \\
\text { the fabrics }\end{array}$ & 7 & 7.3 & 49 & 51 & 33 & 34.4 & 7 & 7.3 & 2.42 & 0.74 & 12 \\
\hline Degradation of fabrics & 3 & 3.1 & 39 & 40.6 & 51 & 53.1 & 3 & 3.1 & 2.56 & 0.61 & 5 \\
\hline $\begin{array}{l}\text { Fungal decay, mould } \\
\text { growth, and dirt in }\end{array}$ & 3 & 3.1 & 35 & 36.5 & 51 & 53.1 & 7 & 7.3 & 2.65 & 0.67 & 3 \\
\hline
\end{tabular}


This is a copy of the 'Post-print'; i.e., final draft post-refereeing.

Wang, C., Abdul-Rahman, H., Wood, L. C., Mohd-Rahim, F. A., Zainon, N., \& Saputri, E. (in press). Defects Of Tensioned Membrane Structures (TMS) in the

Tropics, Journal of Performance of Constructed Facilities

\begin{tabular}{|c|c|c|c|c|c|c|c|c|c|c|c|}
\hline \multicolumn{12}{|l|}{ membrane } \\
\hline \multicolumn{12}{|l|}{ Anchorages } \\
\hline Corrosion in anchor cables & 3 & 3.1 & 39 & 40.6 & 45 & 46.9 & 9 & 9.4 & 2.63 & 0.7 & 4 \\
\hline Deflection of anchor & 8 & 8.3 & 48 & 50 & 33 & 34.4 & 7 & 7.3 & 2.41 & 0.75 & 14 \\
\hline \multicolumn{12}{|l|}{ Cables/ropes } \\
\hline $\begin{array}{l}\text { Slack or drooping } \\
\text { cable/ropes }\end{array}$ & 4 & 4.2 & 53 & 55.2 & 35 & 36.5 & 4 & 4.2 & 2.41 & 0.64 & 13 \\
\hline Corrosion in cables & 3 & 3.1 & 45 & 46.9 & 43 & 44.8 & 5 & 5.2 & 2.52 & 0.65 & 7 \\
\hline \multicolumn{12}{|l|}{ Mast/pole } \\
\hline Deflection of the mast & 7 & 7.3 & 53 & 55.2 & 30 & 31.3 & 6 & 6.3 & 2.36 & 0.71 & 16 \\
\hline Position changed of mast & 11 & 11.5 & 49 & 51 & 33 & 34.4 & 3 & 3.1 & 2.29 & 0.71 & 17 \\
\hline \multicolumn{12}{|l|}{ Rings and Arches } \\
\hline $\begin{array}{l}\text { Corrosion of the rings and } \\
\text { arches }\end{array}$ & 6 & 6.3 & 37 & 38.5 & 49 & 51 & 4 & 4.2 & 2.53 & 0.68 & 6 \\
\hline \multicolumn{12}{|l|}{ Fixings } \\
\hline $\begin{array}{l}\text { Corrosion or fatigue in } \\
\text { fixings }\end{array}$ & 2 & 2.1 & 37 & 38.5 & 49 & 51 & 8 & 8.3 & 2.66 & 0.66 & 2 \\
\hline \multicolumn{12}{|l|}{ Foundation } \\
\hline Cracks in foundation & 12 & 12.5 & 42 & 43.8 & 35 & 36.5 & 7 & 7.3 & 2.39 & 0.8 & 15 \\
\hline \multicolumn{12}{|l|}{ Roof } \\
\hline $\begin{array}{l}\text { Deterioration of roof } \\
\text { coatings }\end{array}$ & 2 & 2.1 & 38 & 39.6 & 41 & 42.7 & 15 & 15.6 & 2.72 & 0.75 & 1 \\
\hline \multicolumn{12}{|l|}{ Services } \\
\hline Lighting breakdown & 12 & 12.5 & 51 & 53.1 & 31 & 32.3 & 2 & 2.1 & 2.24 & 0.7 & 18 \\
\hline Water drainage and ponding & 6 & 6.3 & 44 & 45.8 & 42 & 43.8 & 4 & 4.2 & 2.46 & 0.68 & 11 \\
\hline
\end{tabular}

\section{Pearson Correlation among Defects}

Pearson correlation was used to examine whether there is inter-correlation between the five most frequently occurring defects in tropical TMSs. The strength of relationship value "r" for Pearson correlation was defined by Weinberg and Abramowitz (2002) as a) no relationship if $0 \leq \mathrm{r}<0.1$; b) a weak relationship if $0.1 \leq \mathrm{r}<0.3$; c) a moderate relationship if $0.3 \leq \mathrm{r}<0.5$; and d) a strong relationship if $r \geq 0.5$. As illustrated in Table 7, a strong correlation between "degradation of fabrics" and "fungal decay, mould growth, and dirt in membrane” $(\mathrm{r}=0.521)$ was found at the 0.01 significance level. There were two moderate relationships identified: first, between "deterioration of roof coatings" and “corrosion or fatigue in fixings" ( $\mathrm{r}=0.333$ ); second, between "deterioration of roof coatings" and “degradation of fabrics” $(r=0.302)$. Both were significant at the 0.01 level. The other relationships were weak $(r<0.3)$.

Table 7: Pearson correlation among the five most frequently occurring TMS defects in the tropics 


\begin{tabular}{|c|c|c|c|c|c|c|}
\hline & & $\begin{array}{c}\text { Deterioration } \\
\text { of roof } \\
\text { coatings } \\
\end{array}$ & $\begin{array}{l}\text { Corrosion or } \\
\text { fatigue in } \\
\text { fixings } \\
\end{array}$ & $\begin{array}{l}\text { Fungal decay, } \\
\text { mould growth, and } \\
\text { dirt in membrane }\end{array}$ & $\begin{array}{l}\text { Corrosion } \\
\text { in anchor } \\
\text { cables }\end{array}$ & $\begin{array}{c}\text { Degradation } \\
\text { of fabrics }\end{array}$ \\
\hline Deterioration of roof coatings & $\begin{array}{l}\text { Pearson } \\
\text { Correlation } \\
\text { Sig. (2-tailed) } \\
\mathrm{N}\end{array}$ & $\begin{array}{l}1 \\
96 \\
9\end{array}$ & Moderate & Weak & Weak & Moderate \\
\hline Corrosion or fatigue in fixings & $\begin{array}{l}\text { Pearson } \\
\text { Correlation } \\
\text { Sig. (2-tailed) } \\
\mathrm{N} \\
\end{array}$ & $\begin{array}{l}.333^{* \pi} \\
.001 \\
96 \\
\end{array}$ & $\begin{array}{l}1 \\
96 \\
\end{array}$ & Weak & Weak & Weak \\
\hline $\begin{array}{l}\text { Fungal decay, mould growth } \\
\text { and dirt in membrane }\end{array}$ & $\begin{array}{l}\text { Pearson } \\
\text { Correlation } \\
\text { Sig. (2-tailed) } \\
\mathrm{N} \\
\end{array}$ & $\begin{array}{l}.284^{* *+} \\
.005 \\
96\end{array}$ & $\begin{array}{l}.223^{*} \\
.029 \\
96\end{array}$ & $\begin{array}{l}1 \\
96 \\
\end{array}$ & Weak & Strong \\
\hline Corrosion in anchor cables & $\begin{array}{l}\text { Pearson } \\
\text { Correlation } \\
\text { Sig. (2-tailed) } \\
\mathrm{N}\end{array}$ & $\begin{array}{l}.218^{*} \\
.033 \\
96\end{array}$ & $\begin{array}{l}.264^{* *} \\
.009 \\
96\end{array}$ & $\begin{array}{l}.255^{*} \\
.012 \\
96\end{array}$ & $\begin{array}{l}1 \\
96\end{array}$ & Weak \\
\hline Degradation of fabrics & $\begin{array}{l}\text { Pearson } \\
\text { Correlation } \\
\text { Sig. (2-tailed) } \\
\text { N }\end{array}$ & $\begin{array}{l}.302^{* *} \\
.003 \\
96\end{array}$ & $\begin{array}{l}.300^{* *} \\
.003 \\
96\end{array}$ & $\begin{array}{l}.521^{* *} \\
.000 \\
96\end{array}$ & $\begin{array}{l}.227^{*} \\
.026 \\
96\end{array}$ & $\begin{array}{l}1 \\
96\end{array}$ \\
\hline
\end{tabular}

\section{Identifying Predictor Variables}

Normally, the roof of a TMS is difficult to assess due to the nature of the structure. Perhaps this is partly the cause of "deterioration of roof coatings" being the most common type of defect as it is not checked as frequently as it should be. However, the situation indicates that if there were a useful measure that could be made that would indicate the presence of deterioration in the roof coatings, then maintenance staff would only need to check the roof if there were a suspicion that a check may be required; if the predictor variable indicated that there were no problems then the difficult check of the roof could be avoided. Multiple regression is commonly used to explore relationships between one continuous dependent variable and a number of independent variables so that a predictor can be found. In this study, the regression test examined whether the most frequently occurring TMS defect ("deterioration of roof coatings”) has a linear relationship with the second, third, fourth, or fifth most common defects. Table 8 
shows the model summary, showing the percentage of variability in the dependent variable accounted for by all independent variables. This table provides the " $R$ " value which indicates how well the regression model fits the data. The " $R$ " is a measures the quality of the prediction. In this case, the value of 0.424 indicated a moderately good level of prediction.

Furthermore, Table 9 shows the statistical significance of ANOVA in multiple regressions. The F-test indicates whether the model is a good fit for the data according to the $p$-value. In this case, the independent variables significantly predicted the dependent variable, $F(4,91)=4.974, p<0.001$. The coefficients for the dependent variables are shown in Table 10. The coefficient for "corrosion or fatigue in fixings" at 0.269 is significantly different from 0 because its $p$-value is 0.022 (i.e., $p<0.05$ ). However, the coefficients for the other variables are not significant ( $\mathrm{p}>0.05$ ); therefore, only "corrosion or fatigue in fixings" is valuable as a predictor for the tropical TMS defect "deterioration of roof coatings". While we cannot take this as a causal effect, the correlation does indicate that in practice, TMS maintenance staff do not have to climb up to the roof to check the deterioration of the coating; rather, they need only predict the deterioration of the coating by measuring the corrosion levels of the fixings.

Table 8: Model Summary for Dependent Variable

\begin{tabular}{|c|r|r|r|r|}
\hline Model & R & R Square & Adjusted R Square & $\begin{array}{c}\text { Std. Error of the } \\
\text { Estimate }\end{array}$ \\
\hline 1 & $.424^{\mathrm{a}}$ & .179 & .143 & .694 \\
\hline
\end{tabular}

a. Predictors: (Constant), Degradation of fabrics, Corrosion in anchor cables, Corrosion or fatigue in fixings, Fungal decay, mould growth, and dirt in membrane

b. Dependent Variable: Deterioration of roof coatings

Table 9: ANOVA for Dependent Variable 


\begin{tabular}{|rl|r|r|r|r|r|}
\hline Model & & \multicolumn{1}{|c|}{$\begin{array}{c}\text { Sum of } \\
\text { Squares }\end{array}$} & df & $\begin{array}{c}\text { Mean } \\
\text { Square }\end{array}$ & F & \multicolumn{1}{|c|}{ Sig. } \\
\hline \multirow{2}{*}{1} & Regression & 9.582 & 4 & 2.396 & 4.974 & $.001^{\mathrm{b}}$ \\
& Residual & 43.824 & 91 & .482 & & \\
& Total & 53.406 & 95 & & & \\
\hline
\end{tabular}

a. Dependent Variable: Deterioration of roof coatings

b. Predictors: (Constant), Degradation of fabrics, Corrosion in anchor cables, Corrosion or fatigue in fixings, Fungal decay, mould growth, and dirt in membrane

Table 10: Coefficient for Dependent Variable

\begin{tabular}{|c|c|c|c|c|c|c|c|c|c|c|c|c|c|}
\hline & \multirow{2}{*}{ Model } & \multicolumn{2}{|c|}{$\begin{array}{l}\text { Unstandardized } \\
\text { Coefficients }\end{array}$} & \multirow[t]{2}{*}{$\begin{array}{l}\text { Standardized } \\
\text { Coefficients }\end{array}$} & \multirow{2}{*}{$\mathrm{t}$} & \multirow{2}{*}{ Sig. } & \multicolumn{2}{|c|}{$\begin{array}{l}\text { 95.0\% Confidence } \\
\text { Interval for B }\end{array}$} & \multicolumn{3}{|c|}{ Correlations } & \multicolumn{2}{|c|}{ Collinearity Statistics } \\
\hline & & $\mathrm{B}$ & $\begin{array}{l}\text { Std. } \\
\text { Error }\end{array}$ & & & & $\begin{array}{l}\text { Lower } \\
\text { Bound }\end{array}$ & $\begin{array}{l}\text { Upper } \\
\text { Bound }\end{array}$ & $\begin{array}{c}\text { Zero } \\
- \\
\text { order }\end{array}$ & Partial & Part & Tolerance & VIF \\
\hline \multirow{5}{*}{1} & (Constant) & .910 & .419 & & 2.171 & .033 & .077 & 1.742 & & & & & \\
\hline & $\begin{array}{l}\text { Corrosion or } \\
\text { fatigue in fixings. }\end{array}$ & .269 & .115 & .237 & 2.329 & .022 & .040 & .498 & .333 & .237 & .221 & .867 & 1.153 \\
\hline & $\begin{array}{l}\text { Fungal decay, } \\
\text { mould growth, } \\
\text { and dirt in } \\
\text { membrane. }\end{array}$ & .152 & .127 & .135 & 1.197 & .234 & -.100 & .405 & .284 & .125 & .114 & .708 & 1.413 \\
\hline & $\begin{array}{l}\text { Corrosion in } \\
\text { anchor cables. }\end{array}$ & .096 & .108 & .089 & .884 & .379 & -.119 & .310 & .218 & .092 & .084 & .886 & 1.129 \\
\hline & $\begin{array}{l}\text { Degradation of } \\
\text { fabrics. }\end{array}$ & .172 & .140 & .140 & 1.229 & .222 & -.106 & .450 & .302 & .128 & .117 & .690 & 1.449 \\
\hline
\end{tabular}

\section{Causes and Countermeasures of TMS Defects in the Tropics}

In this section, respondents could choose more than one option. Table 11 ranked the causes of each tropical TMS defect; viz., weather, design, construction/installation process, aging, user involvement, cost pressures, workmanship, material selection, and fabrication techniques. The top four causes for the "fabrics may be tearing" defect are the weather (79.15\%), material selection (50.00\%), aging (50.00\%), and materials (50.00\%). The top three causes for "folding and scratches of the fabric" are: weather 
This is a copy of the 'Post-print'; i.e., final draft post-refereeing.

Wang, C., Abdul-Rahman, H., Wood, L. C., Mohd-Rahim, F. A., Zainon, N., \& Saputri, E. (in press). Defects Of Tensioned Membrane Structures (TMS) in the

Tropics, Journal of Performance of Constructed Facilities

(53.13\%), material selection (41.67\%), and aging (37.50\%). Likewise, all the 18 types of TMS defects have their respective causes identified in Table 11. In general, weather is the top reason for all the TMS defects in tropics (a total score of 939), followed by aging (621), design (609), construction/installation (600), material selection (548), workmanship (427), fabrication techniques (331), user involvement (324), and cost pressures (322). There were seven countermeasures recommended by respondents and each scored from 1 to 5, including: a) use high quality materials; b) select workers that exhibit good behavior; c) schedule regular maintenance; d) increase TMS budgets; e) examine the design procedures and consider drainage, durability, and tensile stress; f) use proper construction/installation processes; and g) gain certification for TMS contractors (Table 12).

Table 11: Causes of TMS defects in the tropics

\begin{tabular}{|c|c|c|c|c|c|c|c|c|c|}
\hline $\begin{array}{l}\text { Type of } \\
\text { Defects }\end{array}$ & Weather & Design & $\begin{array}{l}\text { Construction/ } \\
\text { installation } \\
\text { process }\end{array}$ & Aging & $\begin{array}{c}\text { User } \\
\text { involvement }\end{array}$ & $\begin{array}{c}\text { Cost } \\
\text { pressure }\end{array}$ & Workmanship & $\begin{array}{l}\text { Material } \\
\text { selection }\end{array}$ & $\begin{array}{l}\text { Fabrication } \\
\text { techniques }\end{array}$ \\
\hline Fabrics tear & $\begin{array}{l}76 \\
(79.15 \%)\end{array}$ & $\begin{array}{l}45 \\
(46.88 \%)\end{array}$ & $\begin{array}{l}32 \\
(33.33 \%)\end{array}$ & $\begin{array}{l}48 \\
(50 \%)\end{array}$ & $\begin{array}{l}12 \\
(12.5 \%)\end{array}$ & $\begin{array}{l}12 \\
(12.5 \%)\end{array}$ & $\begin{array}{l}29 \\
(30.21 \%)\end{array}$ & $\begin{array}{l}48 \\
(50 \%)\end{array}$ & $\begin{array}{l}25 \\
(26.04 \%)\end{array}$ \\
\hline $\begin{array}{l}\text { Folding \& } \\
\text { scratches of } \\
\text { fabric }\end{array}$ & $\begin{array}{l}51 \\
(53.13 \%)\end{array}$ & $\begin{array}{l}31 \\
(32.30 \%)\end{array}$ & $\begin{array}{l}32 \\
(33.33 \%)\end{array}$ & $\begin{array}{l}36 \\
(37.5 \%) \\
\end{array}$ & 17 (17.71\%) & $\begin{array}{l}20 \\
(20.83 \%)\end{array}$ & $\begin{array}{l}32 \\
(33.33 \%)\end{array}$ & $\begin{array}{l}40 \\
(41.67 \%)\end{array}$ & $\begin{array}{l}31 \\
(32.30 \%)\end{array}$ \\
\hline $\begin{array}{l}\text { Wrinkling of } \\
\text { the fabrics }\end{array}$ & $\begin{array}{l}65 \\
(67.71 \%)\end{array}$ & $\begin{array}{l}36 \\
(37.5 \%)\end{array}$ & $\begin{array}{l}31( \\
32.30 \%)\end{array}$ & $\begin{array}{l}40 \\
(41.67 \%)\end{array}$ & 13 (13.54\%) & $\begin{array}{l}18 \\
(18.75 \%)\end{array}$ & $\begin{array}{l}28 \\
(29.17 \%)\end{array}$ & $\begin{array}{l}32 \\
(33.33 \%)\end{array}$ & $\begin{array}{l}31 \\
(32.30 \%)\end{array}$ \\
\hline $\begin{array}{l}\text { Flapping and } \\
\text { fluttering of } \\
\text { the fabrics }\end{array}$ & $\begin{array}{l}51 \\
(53.13 \%)\end{array}$ & $\begin{array}{l}36 \\
(37.5 \%)\end{array}$ & $\begin{array}{l}36 \\
(37.5 \%)\end{array}$ & $\begin{array}{l}33 \\
(34.38 \%)\end{array}$ & 15 (15.63\%) & $\begin{array}{l}18 \\
(18.75 \%)\end{array}$ & $\begin{array}{l}28 \\
(29.17 \%)\end{array}$ & $\begin{array}{l}23 \\
(23.96 \%)\end{array}$ & $\begin{array}{l}29 \\
(30.21 \%)\end{array}$ \\
\hline $\begin{array}{l}\text { Degradation } \\
\text { of fabrics }\end{array}$ & $\begin{array}{l}54 \\
(56.25 \%)\end{array}$ & $\begin{array}{l}31 \\
(32.30 \%)\end{array}$ & $\begin{array}{l}21 \\
(21.88 \%)\end{array}$ & $\begin{array}{l}43 \\
(44.79 \%)\end{array}$ & 18 (18.75\%) & $\begin{array}{l}19 \\
(19.79 \%)\end{array}$ & $\begin{array}{l}21 \\
(21.88 \%)\end{array}$ & $\begin{array}{l}37 \\
(38.54 \%)\end{array}$ & $\begin{array}{l}17 \\
(17.71 \%)\end{array}$ \\
\hline $\begin{array}{l}\text { Fungal } \\
\text { decay, } \\
\text { mould } \\
\text { growth, and } \\
\text { dirt in } \\
\text { membrane }\end{array}$ & $\begin{array}{l}70 \\
(72.92 \%)\end{array}$ & $\begin{array}{l}23 \\
(23.96 \%)\end{array}$ & $\begin{array}{l}21 \\
(21.88 \%)\end{array}$ & $\begin{array}{l}33 \\
(34.38 \%)\end{array}$ & $21(21.88 \%)$ & $\begin{array}{l}11 \\
(11.46 \%)\end{array}$ & $\begin{array}{l}20 \\
(20.83 \%)\end{array}$ & $\begin{array}{l}28 \\
(29.17 \%)\end{array}$ & $\begin{array}{l}16 \\
(16.67 \%)\end{array}$ \\
\hline $\begin{array}{l}\text { Corrosion in } \\
\text { anchor } \\
\text { cables }\end{array}$ & $\begin{array}{l}61 \\
(63.54 \%)\end{array}$ & $\begin{array}{l}27 \\
(28.13 \%)\end{array}$ & $\begin{array}{l}29 \\
(30.21 \%)\end{array}$ & $\begin{array}{l}40 \\
(41.67 \%)\end{array}$ & 18 (18.75\%) & $\begin{array}{l}17 \\
(17.71 \%)\end{array}$ & $\begin{array}{l}13 \\
(13.54 \%)\end{array}$ & $\begin{array}{l}38 \\
(39.58 \%)\end{array}$ & $\begin{array}{l}16 \\
(16.67 \%)\end{array}$ \\
\hline $\begin{array}{l}\text { Deflection of } \\
\text { anchor }\end{array}$ & $\begin{array}{l}36 \\
(37.5 \%)\end{array}$ & $\begin{array}{l}31 \\
(32.30 \%)\end{array}$ & $\begin{array}{l}23 \\
(23.96 \%)\end{array}$ & $\begin{array}{l}36 \\
(37.5 \%)\end{array}$ & $24(25.00 \%)$ & $\begin{array}{l}30 \\
(31.25 \%)\end{array}$ & $\begin{array}{l}22 \\
(22.92 \%)\end{array}$ & $\begin{array}{l}26 \\
(27.08 \%)\end{array}$ & $\begin{array}{l}27 \\
(28.13 \%)\end{array}$ \\
\hline $\begin{array}{l}\text { Slack or } \\
\text { drooping } \\
\text { cable/ropes }\end{array}$ & $\begin{array}{l}39 \\
(40.63 \%)\end{array}$ & $\begin{array}{l}34 \\
(35.42 \%)\end{array}$ & $\begin{array}{l}45 \\
(46.88 \%)\end{array}$ & $\begin{array}{l}23 \\
(23.96 \%)\end{array}$ & 25 (26.04\%) & $\begin{array}{l}14 \\
(14.58 \%)\end{array}$ & $\begin{array}{l}27 \\
(28.13 \%)\end{array}$ & $\begin{array}{l}25 \\
(26.04 \%)\end{array}$ & $\begin{array}{l}13 \\
(13.54 \%)\end{array}$ \\
\hline $\begin{array}{l}\text { Corrosion in } \\
\text { cables }\end{array}$ & $\begin{array}{l}59 \\
(61.46 \%)\end{array}$ & $\begin{array}{l}30 \\
(31.25 \%)\end{array}$ & $\begin{array}{l}27 \\
(28.13 \%)\end{array}$ & $\begin{array}{l}39 \\
(40.63 \%)\end{array}$ & 16 (16.67\%) & $\begin{array}{l}17 \\
(17.71 \%)\end{array}$ & $\begin{array}{l}18 \\
(18.75 \%)\end{array}$ & $\begin{array}{l}34 \\
(35.42 \%)\end{array}$ & $\begin{array}{l}11 \\
(11.46 \%)\end{array}$ \\
\hline
\end{tabular}


This is a copy of the 'Post-print'; i.e., final draft post-refereeing.

Wang, C., Abdul-Rahman, H., Wood, L. C., Mohd-Rahim, F. A., Zainon, N., \& Saputri, E. (in press). Defects Of Tensioned Membrane Structures (TMS) in the Tropics, Journal of Performance of Constructed Facilities

\begin{tabular}{|c|c|c|c|c|c|c|c|c|c|}
\hline $\begin{array}{l}\text { Deflection of } \\
\text { the mast }\end{array}$ & $\begin{array}{l}40 \\
(41.67 \%)\end{array}$ & $\begin{array}{l}35 \\
(36.46 \%)\end{array}$ & $\begin{array}{l}41 \\
(42.71 \%)\end{array}$ & $\begin{array}{l}35 \\
(36.46 \%)\end{array}$ & 22 (22.92\%) & $\begin{array}{l}24 \\
(25.00 \%)\end{array}$ & $\begin{array}{l}23 \\
(23.96 \%)\end{array}$ & $\begin{array}{l}26 \\
(27.08 \%)\end{array}$ & $\begin{array}{l}13 \\
(13.54 \%)\end{array}$ \\
\hline $\begin{array}{l}\text { Position } \\
\text { changed of } \\
\text { mast }\end{array}$ & $\begin{array}{l}44 \\
(45.83 \%)\end{array}$ & $\begin{array}{l}44 \\
(45.83 \%)\end{array}$ & $\begin{array}{l}59 \\
(61.46 \%)\end{array}$ & $\begin{array}{l}22 \\
(22.92 \%)\end{array}$ & $\begin{array}{l}6 \\
(6.25 \%)\end{array}$ & $\begin{array}{l}14 \\
(14.58 \%)\end{array}$ & $\begin{array}{l}18 \\
(18.75 \%)\end{array}$ & $\begin{array}{l}27 \\
(28.13 \%)\end{array}$ & $\begin{array}{l}10 \\
(10.42 \%)\end{array}$ \\
\hline $\begin{array}{l}\text { Corrosion of } \\
\text { the rings and } \\
\text { arches }\end{array}$ & $\begin{array}{l}70 \\
(72.92 \%)\end{array}$ & $\begin{array}{l}29 \\
(30.21 \%)\end{array}$ & $\begin{array}{l}30 \\
(31.25 \%)\end{array}$ & $\begin{array}{l}47 \\
(48.96 \%)\end{array}$ & $\begin{array}{l}6 \\
(6.25 \%)\end{array}$ & $\begin{array}{l}10 \\
(10.42 \%)\end{array}$ & $\begin{array}{l}16 \\
(16.67 \%)\end{array}$ & $\begin{array}{l}26 \\
(27.08 \%)\end{array}$ & $\begin{array}{l}7 \\
(7.29 \%)\end{array}$ \\
\hline $\begin{array}{l}\text { Corrosion or } \\
\text { fatigue in } \\
\text { fixings }\end{array}$ & $\begin{array}{l}54 \\
(56.25 \%)\end{array}$ & $\begin{array}{l}27 \\
(28.13 \%)\end{array}$ & $\begin{array}{l}31 \\
(32.30 \%)\end{array}$ & $\begin{array}{l}31 \\
(32.30 \%)\end{array}$ & 20 (20.83\%) & $\begin{array}{l}10 \\
(10.42 \%)\end{array}$ & $\begin{array}{l}23 \\
(23.96 \%)\end{array}$ & $\begin{array}{l}26 \\
(27.08 \%)\end{array}$ & $\begin{array}{l}14 \\
(14.58 \%)\end{array}$ \\
\hline $\begin{array}{l}\text { Cracks in } \\
\text { foundation }\end{array}$ & $\begin{array}{l}35 \\
(36.46 \%)\end{array}$ & $\begin{array}{l}49 \\
(51.04 \%)\end{array}$ & $\begin{array}{l}47 \\
(48.96 \%)\end{array}$ & $\begin{array}{l}27 \\
(28.13 \%)\end{array}$ & 15 (15.63\%) & $\begin{array}{l}21 \\
(21.88 \%)\end{array}$ & $\begin{array}{l}30 \\
(31.25 \%)\end{array}$ & $\begin{array}{l}31 \\
(32.30 \%)\end{array}$ & $\begin{array}{l}15 \\
(15.63 \%)\end{array}$ \\
\hline $\begin{array}{l}\text { Deterioration } \\
\text { of roof } \\
\text { coatings }\end{array}$ & $\begin{array}{l}61 \\
(63.54 \%)\end{array}$ & $\begin{array}{l}39 \\
(40.63 \%)\end{array}$ & $\begin{array}{l}34 \\
(35.42 \%)\end{array}$ & $\begin{array}{l}33 \\
(34.38 \%)\end{array}$ & 18 (18.75\%) & $\begin{array}{l}17 \\
(17.71 \%)\end{array}$ & $\begin{array}{l}23 \\
(23.96 \%)\end{array}$ & $\begin{array}{l}36 \\
(37.5 \%)\end{array}$ & $\begin{array}{l}17 \\
(17.71 \%)\end{array}$ \\
\hline $\begin{array}{l}\text { Lighting } \\
\text { breakdown }\end{array}$ & $\begin{array}{l}37 \\
(38.54 \%)\end{array}$ & $\begin{array}{l}31 \\
(32.30 \%)\end{array}$ & $\begin{array}{l}38 \\
(39.58 \%)\end{array}$ & $\begin{array}{l}19 \\
(19.79 \%)\end{array}$ & 34 (35.42\%) & $\begin{array}{l}20 \\
(20.83 \%)\end{array}$ & $\begin{array}{l}34 \\
(35.42 \%)\end{array}$ & $\begin{array}{l}19 \\
(19.79 \%)\end{array}$ & $\begin{array}{l}12 \\
(12.5 \%)\end{array}$ \\
\hline $\begin{array}{l}\text { Lack of } \\
\text { water } \\
\text { drainage and } \\
\text { water } \\
\text { pooling }\end{array}$ & $\begin{array}{l}36 \\
(37.5 \%) \\
\end{array}$ & $\begin{array}{l}31 \\
(32.30 \%)\end{array}$ & $\begin{array}{l}23 \\
(23.96 \%)\end{array}$ & $\begin{array}{l}36 \\
(37.50 \%)\end{array}$ & $24(25.00 \%)$ & $\begin{array}{l}30 \\
(31.25 \%)\end{array}$ & $\begin{array}{l}22 \\
(22.92 \%)\end{array}$ & $\begin{array}{l}26 \\
(27.08 \%)\end{array}$ & $\begin{array}{l}27 \\
(28.13 \%) \\
\end{array}$ \\
\hline Total & 939 & 609 & 600 & 621 & 324 & 322 & 427 & 548 & 331 \\
\hline
\end{tabular}

Table 12: Countermeasures of TMS defects in the tropics

\begin{tabular}{|l|l|c|}
\hline No. & \multicolumn{1}{|c|}{ The key factors to increase the feature TMS } & Score \\
\hline 1 & Use high quality material & 5 \\
\hline 2 & Choose workmanship with good behavior & 4 \\
\hline 3 & Scheduled maintenance & 3 \\
\hline 4 & Increase TMS budget & 2 \\
\hline 5 & Examine the design procedure considering drainage, durability, and tensile stress & 2 \\
\hline 6 & Use proper construction/installation process & 2 \\
\hline 7 & Certification for TMS contractors & \\
\hline
\end{tabular}

\section{Critical Discussion about these Findings}


The "deterioration of roof coatings", "corrosion or fatigue in fixings", "fungal decay, mould growth, and dirt in membrane", "corrosion in anchor cables", and "degradation of fabrics" are the five most frequently occurring TMS defects in the tropics. The deterioration of roof coatings is largely caused by the strong ultraviolet radiation in this region. The coating is vital for TMS durability as it contributes to the strength of the fabrics and it protects both the fabrics and the membrane. Shaeffer (2000) ranked the deterioration of roof coatings as only the fourth most frequent defect in his study, and ignored the possible impact of climatic and regional effects. However, in our research, "deterioration of roof coatings" is shown as the most common defect because of the strong solar radiation and intense precipitation; both of which are stronger in the tropics than in other climate zones. This proposition was partially supported when we sought to identify the causes of TMS defects, which indicated that "weather" was regarded as the most significant cause. The maintenance work required for TMS does not need to be frequent and usually no consideration is given to changing the coating, leading to no change over life of the structure even when deterioration occurs. We identified "corrosion or fatigue in fixings" as the second most frequent TMS defect in the tropics due to the poor corrosion protection and weather, this is supported by Macdonald's (2001) assertion that corrosion or fatigue in fixings always occurs in large TMS structures. Further, "fungal decay, mould growth, and dirt in membrane" was identified as the third most frequent defect and the reason may be alluded to in Shaeffer's (2000)'s study which identified that moisture levels and poor maintenance are crucial in TMS construction and use, but which we rank as much more significant, overall. The other kinds of corrosion defects occurring in TMS (e.g., corrosion in anchor cables, rings, arches, and ropes) are primarily due to poor corrosion protection (Foster et al., 2007). Most TMS fabrics in this study were covered by PVC, silicone, or PTFE. The fifth most common TMS defect in the tropics is "degradation of fabrics"; this is strongly correlated with the 
defect "fungal decay, mould growth, and dirt in membrabe", which is logical as when the fabric degrades, the microbes and fungus can more readily impregnate the material.

\section{Conclusions and Recommendations}

While TMS has been applied in the tropics with great success, its defects relative the specific climatic and weather conditions of the region have never been specifically examined. This study identified the most frequently TMS defects in the tropics as "deterioration of roof coatings", "corrosion or fatigue in fixings", "fungal decay, mould growth, and dirt in membrane", "corrosion in anchor cables", and "degradation of fabrics". The relative ranking of these defects is quite different from that found in other climatic zones. The top five causes of TMS defects in the tropics are the weather, aging, design, construction/installation, and material selection. Weather is a primary cause of TMS defects in the tropics more so than in other regions; the UV rays and precipitation place greater strain on the TMS materials. We found that only "corrosion or fatigue in fixings" is a significant predictor for "deterioration of roof coatings"; while this is not a causal effect, it does indicate that TMS maintenance staff do not have to climb up to the roof to check the deterioration of coatings but can instead predict failure by measuring the corrosion of the fixings. There were seven countermeasures recommended: a) using high quality materials; b) selecting workers exhibiting good behaviors; c) scheduling regular maintenance; d) increasing the budget for TMS builds; e) examining the design procedures and considering drainage, durability, and tensile stress; f) using proper construction/installation processes; and, g) implementing a certification programme for TMS contractors. However, these countermeasures have not been analyzed in this study and further research should examine their use in a long-term, 
This is a copy of the 'Post-print'; i.e., final draft post-refereeing.

Wang, C., Abdul-Rahman, H., Wood, L. C., Mohd-Rahim, F. A., Zainon, N., \& Saputri, E. (in press). Defects Of Tensioned Membrane Structures (TMS) in the Tropics, Journal of Performance of Constructed Facilities

longitudinal research design. The countermeasures may need to be tested in new TMS projects and some require policy support. This highlights the importance of future case study research examining TMS defects.

\section{REFERENCES}

Beatini, V., Royer-Carfagni, G. (2013). "Cable-stiffened foldable elastica for movable structures", Engineering Structures, 56, 126-136.

Brew, J.S., Lewis, W.J. (2013). "Spline-based and stress-monitored patterning of fabric structures", Computers \& Structures, 119, 203-214.

Bryman, A., Cramer, D. (2001). Quantitatove Data Analysis with SPSS for Windows. Philadelphia: Routledge.

Campbell, P. (2001). Learning from construction failures. London: Whittles Publishing.

Cheng, Y.J. (2007). Study the defects on building fabric: case study at University of Malaya. Master's Thesis, Universiti Malaya, Kuala Lumpur.

Cook, E.K. Hinks, A.J. (1992). Appraising building defects: perspective on stability and hygrothermal performance. London: Longman Scientific \& Technical.

Foster, J.S., Harington, R., Greeno, R. (2007). Structure and fabric( $7^{\text {th }}$ ed.). London: Person/Prentice Hall.

Foster, J.S. (2000). Structure and fabric (6 $6^{\text {th }}$ ed.). London: Longman. 
Gosling, P.D., Bridgens, B.N., Albrecht, A., Alpermann, H., Angeleri, A., Barnes, M., Bartle, N., Uhlemann, J. (2013a). "Analysis and design of membrane structures: Results of a round robin exercise", Engineering Structures, 48, 313-328.

Gosling, P.D., Bridgens, B.N., Zhang, L. (2013b). "Adoption of a reliability approach for membrane structure analysis", Structural Safety, 40, 39-50.

Guo, L. (2008). "Wrinkling evaluation of membrane structure", In John F. A. \& Robert C. (eds.), Proceedings of the $6^{\text {th }}$ International Conference on Computation of Shell and Spatial Structures IASSIACM 2008: “Spanning Nano to Mega, May 28-31, 2008 (pp. 1-4). USA: Cornell University.

Habib, M.T., Rokonuzzaman, M. (2011). "Distinguishing feature selection for fabric defect classification using neural network", Journal of Multimedia, 6(5), 416-424.

Huntington, C. G. (2009). Design of connections for Tensioned Fabric Structures. Oakland: Huntington Design Assiciates.

Ilozor, B.D., Okoroh, M.I., Egbu, C.E., \& Archicentre. (2004). "Understanding residential house defects in Australia from the state of Victoria", Building and Environment, 39(3), 327-337.

Khoo, Y. M. (2011). A study on the state of quality of low cost housing in the Klang Valley. PhD Thesis, Universiti Malaya, Kuala Lumpur.

Li, F., Yuan, Y. (2013). "Effects of corrosion on bond behavior between steel strand and concrete", Construction and Building Materials, 38, 413-422.

Loong, T.S., Abdul Razak, H., Ismail, Z., Keong, C.K. (2007). "Experimental and numerical formfinding of membrane structures", Asian Journal of Civil Engineering -Building and Housing, 8(1), 1-12.

Low, S.P., Wee, D. (2001). "Improving the maintenance and reducing building defects through ISO 9000", Journal of Quality in Maintenance Engineering, 7(1), 6-24.

Macdonald, A.J. (2001). Structure and architecture ( $2^{\text {nd }}$ ed.). Woburn: Architectural Press. 
Nunes, E.F. (2012). Qualitative investigation of the performance of a structural membrane roof project. PhD Thesis in Civil Engineering, University of Federal De Ouro Preto, Escola De Minas.

Pargana, J.B., Smith, D.L., Izzudin, B.A. (2008). "Realistic modeling of tensioned fabric structures", In

John F. A. \& Robert C. (eds.), Proceedings of the $6^{\text {th }}$ International Conference on Computation of Shell and Spatial Structures IASS-IACM 2008: “Spanning Nano to Mega, May 28-31, 2008 (pp. 1-4). USA: Cornell University.

Pavkov, T.W., Pierce, K.A. (2007). Ready, set, go!: A student guide to SPSS 13.0 and 14.0 for windows. New York: McGraw-Hill.

Richardson, B.A. (2001). Defects and deterioration in buildings ( $2^{\text {nd }}$ ed.). London: Spon Press.

Seidel, M. (2009). Tensile surface structures: A practical guide to cable and membrane construction. Germany: Ernst \& Sohn.

Shaeffer, R.E. (1996). Tensioned membrane structures. U.S.A.: American Society of Civil Engineers (ASCE).

Sommerville, J. (2007). "Defects and rework in new build: an analysis of the phenomenon and drivers", Structural survey, 25(5), 391-407.

Supartono, F.X., Li, Z., Wang, X. (2011). Membrane structure: a modern and aesthetic structural system. Paper presented at the Seminar dan Pameran HAKI, Indonesia.

Tian, D. (2011). Membrane materials and membrane structures in architecture. Unpublished master's thesis, The University of Sheffield, UK.

Toyoda, M., Takahashi, D. (2013). "Reduction of rain noise from Ethylene/Tetra Fluoro Ethylene membrane structures", Applied Acoustics, 74(12), 1309-1314.

Weinberg S.L., Abramowitz, S.K. (2002). Data Analysis for Behavioral Science using SPSS. Cambridge University Press. 